月本細菌學雜誌，7(6)，1952

\title{
電子顯微鏡によるスピロヘータの研究
}

\section{その三 単咬症病原体について}

\author{
朝 倉 善 作 \\ 京都大学医学部微生物学敉室（主任 木村廉敎授）
}

単咬症病原体は本邦に於てはその形態学的特徵及び性 狀からして一般にスピロへータの一つとして取报われて いるが，異論があり Spirillum に属すと主張する研究 者 (Adachi, 1) Ch. Ruys, 2) Robertson, 3) Topley and Wilson, 4) Breed et al ${ }^{5}$ ) も少くなく, 叉論議の余地あ りとする人々(Bayne-Jones, 6) Noguchi, 7) Mühlens ${ }^{8)}$ ) ああり，分類学上決定的な結論が出されていない。

Spirillum 貸を唱うる人々は Spirillum には鞭毛が存 在する, 細胞体が硬固である, 彎曲が本面的屈曲であつ て螺旋でない等の点が Spirochaeta との差晎であると述 ベ，之を論拠とし本微生物は之に該当するが故に゙ Spirullm であるとしている。しかしながら，最近スピロ一 一タにも鞭毛を有するすのが認められて来た故 Spiirllum と Spirochaeta との区別は甚だ团難となつて来てい る。（木村廉著 細菌学及び免疫学 7 版 4 頁昭和 26 . 参 照)

著者は第一者 9) に於てスピロニータの電子㙷微鏡的 研究つ交献を紹介すると共に Borrelia duttonii につい て，第二報 ${ }^{10)}$ に於ては Leptospira 5 株について電子 鏡檢し観察せる所を報告した。今回は本邦に於ける一般 慣例と著者自身の見解により本微生物をスピローータの 電子顯微鏡的研究の中に暫定的に包括し, 之によつて得 られる知見が分類学上にす何か資料を與えるのではない かと考え探り上げた次第である。

本微生物の電子㙷微鏡的研究は著者の調べた範囲では 末だ報告されていないようである。なお本微生物の分類 学的方面は他日別稿にて論述する予定である。

\section{実驗}

供試スタムは当教室に於てマウスに接種, 継代保存し ある人系長谷川株と単系京大微生株の 2 株である。

試料調製方法 上記スタムをマウスに接種しその腹腔 液を材料とした。本微生物は感染マウスの血液中には勿 論腹腔液中にも多数出現することは矿究初期より知られ ていたが，西沢・鯛瀨 11)は本現象について緻善な観察を 行い, 腹腔液中には血液中よりも恒常多数出現すると報
告している。

スピローータの電子顯微鏡試料の調製にあたり被檢体 を生体材料に求める場合には精製を必要とすることは著 者の第一報 ${ }^{9)}$ に於て詳しく述べた所である。それ故精 製の容易なることからして夾雜物が少く，又被檢体の豊 富な腹腔液を用いることは血液を材料とするよりも滛か に賢明である。

さて, 西沢・鯛瀨は本微生物が感染マウスの血液中よ りも腹腔液中に多数出現すると報告したのは前述の如く であるが，著者の体驗では每常必らずしもそうではな く, 又稀に多数出現することがあつても決して精製時の 損耗に耐える程の著明なものでないことが屢々あつた。 か〉る場合には福島氏法 ${ }^{12)}$ による增菌を試みた。即ち， マウスに接種後 7〜10 日して感染を確認し, 每日若しく は隔日に非働性家鬼血涌（クェン酸で $\mathrm{pH} 6.0$ に修正せ るもの） $0.2 \sim 0.3 \mathrm{cc}$ 宛腹腔內に注大すること数回，然 る時には本微生物は該マウス腹腔液中に無数に增加出現 する。之を毛細管ピンットで穿刺探取し，分劃遠沈，集 菌洗條して精製した。一回の試料調製には30〜50 匹の マウスを使用した。それは一匹のマウスから無理をせず に採取し得る腹腔液の量は $0.1 \sim 0.2 \mathrm{cc}$ であり，精製過 程に於て相当の損耗を招来する故多数の文スを使用す ることが望ましいからである。

マウスは本微生物を終生保菌すると雖も，一度使用し たマウスに再度上記增菌法を試みても失敗に終ることが 多かつた故試料調製には恒常新に感染せしめたマウスを 使用しなければならながつた。

腹腔液中の粗大有形成分 (主に白血球)の分離には 1000 回轉 5 分間遠心沈澱するか, 又は腹腔液を人れた遠沈管 をそのま〉数時間乃至十数時間水室內に靜置することに

ASAKURA Zensaku: Studies of the Spirochaetes as revealed by the Electron Microscope. III. Microorganisms of Rat-bite fever. Microbiological Institute, Medical Faculty of Kyoto University. Director : Prof. Kimura Ren M. D. - Jap. J. of Bact., 7(6) : 567-570, 1952. 
することにより行つた。集菌, 洗桬は 4,000 回轉 30 分間 遠心沈澱する事により洗策液としては通常生理的食塩水 を使用した。.しかし乍ら，夾雜物を完全に除去すること は甚だ困難であつて，而も本微生物の損耗も相当大であ る故余程懭重を期さねば精製は失敗に終ることが多い。

著者の体驗では每回かくして調製した数十コの試料の 5ち実際鏡檢に耐えるのはその5ち $1 / 10$ 位に過ぎない程 であつた。かくして精製終了後適宜の浮游液をつくり, コロジオン膜上に載せて乾燥し電子鏡檢した。之には島 津 SM-I 型及び京大案型電子㙷微鏡, 加速電圧 40 50 KVを使用した。

\section{所見と考䕓}

本微生物の形態学的特徽は光学繖微鏡によつて相当緻 密㳊観察されている。之等によれば，本微生物は体部之 その两端にある鞭毛より成立つている。そして他のスピ ローータに比し卙だしく太短い、体部は螺旋乃至屈曲を示 し，太い鞭毛はゆるやかな彎曲を示し体部より長い場合 が多いと。特に Ch. Ruys ${ }^{13)}$ や McDermott 14) は本微 生物の回旋はコルク栓拢狀の螺旋ではなくて平面的な屈 曲であると見做した。しかし乍ら，之等は主として染色 標本における観察であつて，吾々は暗視野鏡檢により明 かに螺旋狀態として認めることが出来る。このことは Borrelia や Leptospira に於ても同様で，生きている 一一活潑に運動している場合明白に認められる螺旋形態 が，㶳弱一渾動停止するにつれてその蝃旋が積み，又 固定染色すること及び外界の影響等により死の狀態にな つた場合螺旋がのびて單なる本面的な彎曲乃至屈曲とな ることを示するのであろう。

換言すれば, 被檢体をメディームの中に浮游せしめる ことうガラス面に固定せしめる標本調製方法の差巽が被 檢体の新鮮陳旧さと組合されて，夫々螺旋か或は彎曲乃 至屈曲であるとの結論に導くのであろう。

著者の電子像に於ては螺旋形態が推測出来る場合 (Fig. I, II, IV) と彎曲乃至屈曲形態を示す場合 (Fig. III, V, VI, VII, VIII)の二樣がみられるが, 之は恐らく 前述の理由と精製過程の差異の如何によるのであろう。 そして電子隰微鏡の分解能が大であることる関與して いるのであろう。螺旋形態がのびて長くなることは Mudd 等 15) Lofgren 等 16) Hampp等17) も Treponema や Borrelia で認めている。

以上のことからして本微生物の体部は螺旋狀態でな、 て本面的な屈曲であるとの Ch. Ruys ${ }^{13)}$ や MacDermott 14) の如き断定は適当でないと思われる。

Fig. I, III の電子像をよく観察すると体部楇緣に電子
線透過性のよい薄層がみられる。

之は細胞体の周線に slime-layer 樣構造のあることを 示しているのかも知れない。

Fig. I〜VII では細胞体は何れも電子線の透過性がよ くないことを示しているが，Fig. VIII では透過性がか なり良好で內部に 1 箇の顆粒の像が認められる。第一報 に於て Borrelia duttonii の細胞体內部が必らずしも均 一でなく多樣の像を示し 顆粒も存在し, 恐らく之等は Borrelia に life-cycle があることを示しているのではな かろらかと述べたが， Fig. VIII の像からして本微生物 に於ても同樣のことが云い得るのではなかららかと考党 られる。

楩毛は太いのが一本宛細胞体の両端に存在することは 周知の事実であり吾々は曋視野鏡檢により谷易にみるこ とが出来る。ところが, Zuelzer, 18) Adachi, 1) Robertson ${ }^{3)}$ 等は両端に 数本宛の鞭毛が存在し，それ等が束 狀になつていると記載している。特に Adachi 1) は氏独 得の染色法にて鞭毛を観察し, demonstrable flagella の 数は標本作製手技により変るようであり，又鞭毛は細い ものが数本末端に発生し1 本の太いものに融合し, 或は 太い鞭毛が数本の細いものに分岐すると述べている。

二末 ${ }^{19)}$ は之を否定してか〉る像は人工童物であると 結論した。

著者の電子像 (Fig. II, III, IV, V, VI) では本微生 物の太い 1 本の鞭毛は実はより細い数本の緎維から出来 ていることが解つた。之等の細鐵維を夫々 1 本の鞭毛と 見做すべきか，或は東狀潗合した太いものを 1 本の鞭 毛と考学るかにより多毛說と1本說とに分かれる。

なお Hampp 等17)の研究によれば Borrelia vincenti や Treponema pallidum の鞭毛は数本の 細繊䊒から出 来て束狀となつていると, 藷者も Borrelia duttonii で 同樣の所見を得ている。又近く Leifson 20)は Borrelia novyi の染色標本に於て甚だ太い鞭毛の像を得ている。 それ故著者は二木や Adachi の見解を併せ鑑み次の如く 主張したい。

『スピロヘータ（特に本微生物）の鿒毛は光学慜微鏡 では通常單一織維として認められるけれども, 実はより 細い数本の緎維より出来ていて外から加わる影響により 容易に分條し，又本微生物の life-history に伴い自然に 数本の細繊維に分岐分條する場合がある。而も試料調製 及び染色方法と観察條件の相違等が鞭毛分條像の暴なつ た狀態を示し, 光学㙷微鏡と電子㪚微鏡の解像力の差が 义之に関與する所大である』と。

本微生物の鞭毛とスピローータの終未系とは附着部位。 
が何れも terminal である故よく似た感を抱かしめる が，本微生物の鞭毛が数本の細瀻維から出来ていること と Hampp 等12)が報告した Borrelia vincentii の電子 像で終末系が数本の細緗維から出来ていることは共通し た興味深い点である。今後之等について更に追求してみ たい。

\section{要 約}

鼡咬症病原休 2 株を電子鏡檢し, 得た電子像と從来の 光学㙷微鏡による記載とを対比しつ子論述した。即ち, 体部の螺旋----屈曲渴する筧解を述へ，体周線に sl一 ime-layer 樣檴造, 內部顆粒の存在する 場合のあること を記載し，鞭毛は数本の 細穖維よりなることを確認し た。な打試料調製方法について詳述した。

擱等にあたり御挴篤なる御指導と御校閱を赐わりたる 恩師木村廉敎授に感謝の誠を捧ぐ。本論交の写县はすべ て畏友尾崎良克学士の撮影によるもので，島津製作所研 究部長島津新一博士及び研究部御一同は溫き御同情を以 て同研究部の SM-I 型電子㙷微鏡の㑊用を許された。妶 に满腔の感謝の意を表したい。なお滯米中の東犁助敉授 より絶えざる激励と助言を戴いた。。深謝の意を表す。

\section{文献}

1) Adachi, K.: Flagellum of the Microorganisms of Rat-bite fever, J. Exp. Med., 33, 647-651, 1921.

2) Ch. Ruys.: Klassifikation des Erregers der Rattenbisskrankheit, Zbl. f. Bakt., I. Orig., 103, S. 258, 1927.

3) Robertson, A.: Chapter VIII Rat-bite fever or Sodoku. from A System of Bacteriology, by Bulloch et al 1931 .

4) Topley and Wilson.: Chapter 36. The Spirochaetes, The Principles of Bacteriology and Immunity. 1946.

5) Breed, R. S., et al.: Bergey's Manual of determinative Bacteriology. 6 th Ed. 212-216. 1948.

6) Bayne-Jones, S.: N. York State J. M., 27, 1113, 1927. cited from Zinsser's Textbook of Bacteriology, 9 th Ed. 636, 1948, by Smith and Martin.

7) Noguchi, H.: Chapter 36. The Spirochetes. from the newer knowledge of bacterioiogy and immunology, by Jordan and Falk. 1928.

8) Mühlens, P.: Verschiedene als pathogen angesehene Spirochaeten. G. Die Spirochaeten bzw. Spirillen beim Rattenbissfieber (japanisch: Sodoku), von Handbuch der pathogene Mikroorganismen (Koolle und Wassermann). Bd. 7, Tl. 2, 800-807, 1931.

9）朝倉善作：電子顯微鏡によるスピロへータの研 究. その一緒言並に Borrelia duttonii について, 最新医学, 6 卷, 10 号, 71-77, 昭 26. (1951).

10）朝倉善作：電子顯微鏡による スピロへータの研 究. その二 Leptospira について, 日本細菌学雜 誌, 7, 335-337, 昭 27. (1952).

11）西沢行藏，觡䒜國一：南京単腹腔液中に出現す る爯咬症スピローータの研究(其の一), 実驗医学 雜誌, 15, 967-992, 眧6. (1931).

12）福島伴次：木村廉著 細菌学及び急疫学. 4 版. 第 4 章 VI 巣咬症スピローータ, 346. 昭 23. (1948) より引用.

13) Ch. Ruys.: Der Erreger der Rattenbisskrankheit, A. f. Schiffs u. Trop. Hyg., Bd. 30, S. $112,1926$.

14) McDermott. : Rat-bite fever, Quarterl. J. Med.. Bd. 21, S. 433, 1928.

15) Mudd, S. et ial. : Bacterial Morphology as shown by the Eectron Microscope. V. Trepo. nema pallidum, T. macrodentium and T. microdentium. J. Bact., 46, 15-24, 1943.

16) Lofgren, R. and Soule, M. H.: The Structure of Spirochaeta movyi as revealed by the Electron Microscope, J. Bact., 56, 679-690, 1945.

17) Hampp, E. G. et al.: Morphologic Characteristics of Certain Cultured Strains of Oral Spirochetes and Treponema pallidum as revealed by the Electron Microscope, J. Bact., 56, 755 $-769,1948$.

18) Zuelzer, M.: Biologische und systematische Spirochaetenuntersuchungen, Zbl. f. Bakt., I Orig, Bd. 85, S. 154, 1921.

19）二木謙三：㸺咬症, 東西医学大観， 2 号，15-21, 昭 2. (1927).

20) Leifson, E. : The flagellation of Spirochetes, J. Bact., 60, 678-679, 1950. 
附図說明
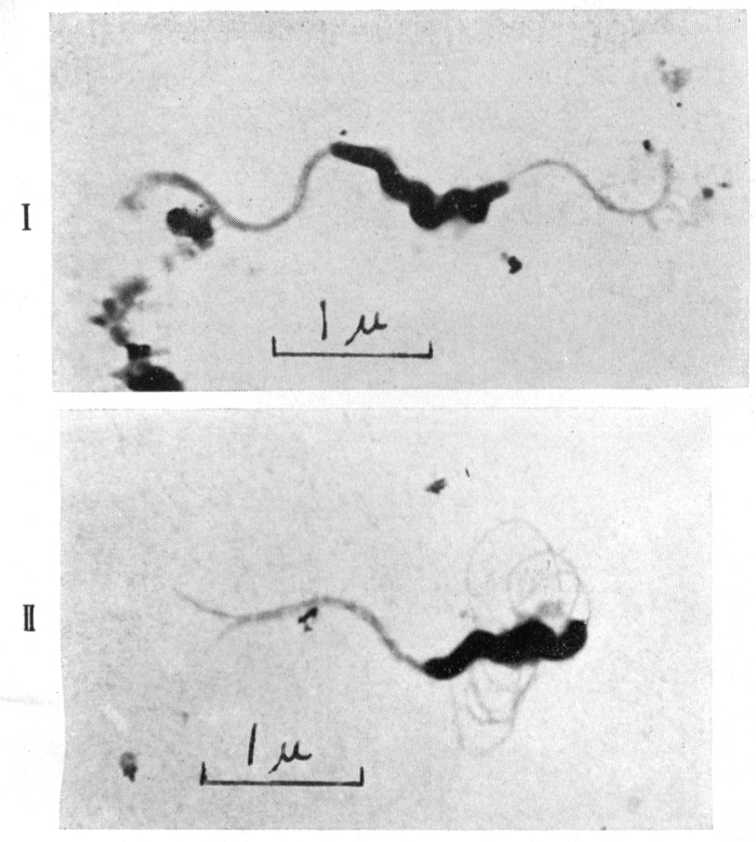

II
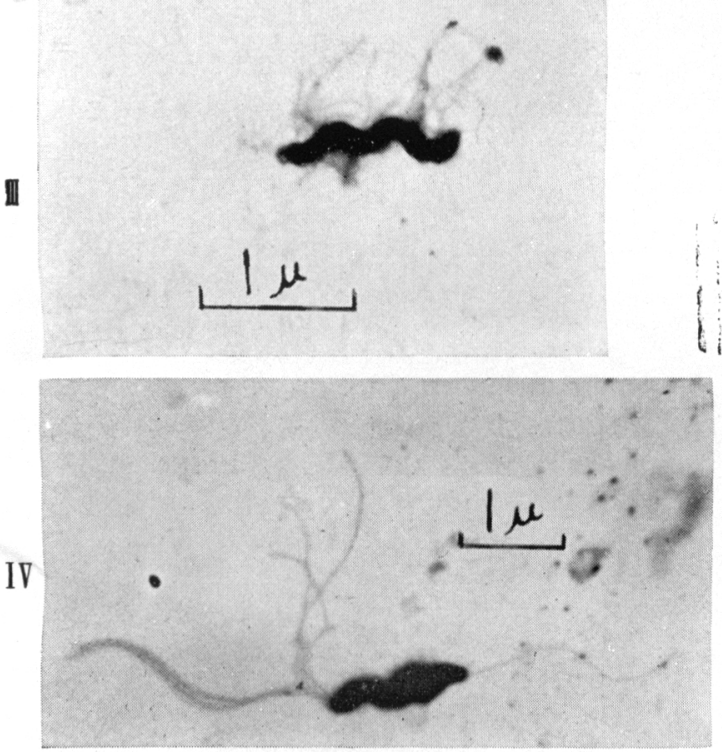

Fig. I-III は人采長谷川株の電子像

Fig. I 体部螺旋狀, 周緣に電子線の透過性のよい薄 痸がみられる。両端に太い㬮毛が一本宛あ り。

Fig. II 一端の鞭毛は太く先端で二つに分岐してい る。他の鞭毛は数本の細瀻維に分條し絡みあ つている。

Fig. III 周辺に薄蟹をみとめ, 㬮毛は分條し細胞体に からみついている。

Fig. IV-VIII は単系京大微生株の電子像

Fig. IV 一端の鞭毛は太く体部に近い所で二群に分れ
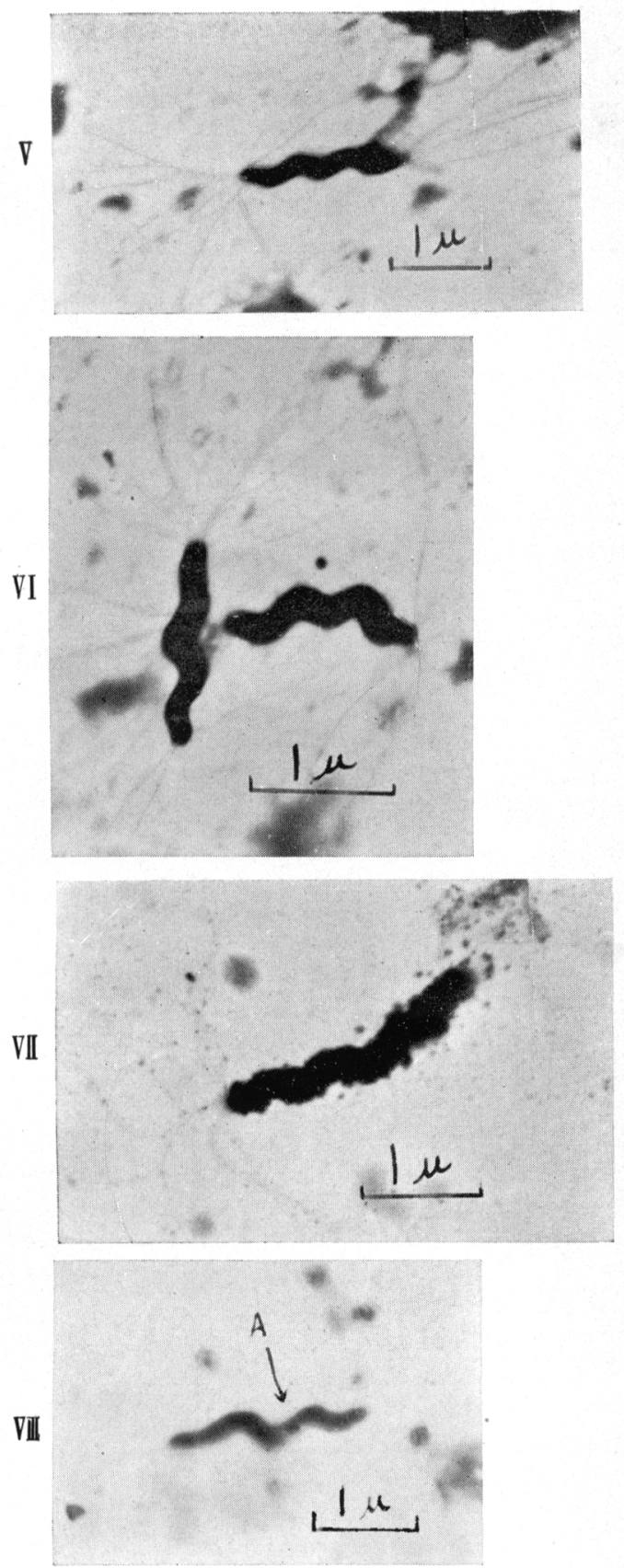

一群は細纎維が二本密着し，他群は三本に分 れている。他端は細絟維一本のみである。

Fig. V 体部は平面的彎曲を示し, 両端の鞭毛は各々 数本の細繊維に分散している。

Fig. VI 同上:

Fig. VII 体部に多数の微細顆粒が附着している。顆粒 の意義不明。

Fig.VIII 細胞体の電子線の透過性はかなり良好で，原 形質の分布は均一でなく, 內部顆粒の像 (A) がみられる。 